\title{
Nexus between Debt and Economic Growth: Evidence from Pakistan
}

\author{
Amna Sohail Rawat*
}

\begin{abstract}
The present study aims to analyse the link between external debt, domestic debt and economic growth for Pakistan. To serve the purpose, the study uses the data for the time period from 1987 to 2018. Various econometric techniques i.e, fully modified ordinary least squares model, dynamic ordinary least squares model have been employed to estimate the proposed model. The empirical findings suggested that there exist a negative relationship between growth and debt whether it is external or domestic. The study confirmed the existence of debt overhang effect in the economy. It is suggested that Pakistan should reduce her reliance on external and domestic debt and should concentrate over increasing their tax and non-tax revenues to finance fiscal expenditures.
\end{abstract}

Keywords: External debt, domestic debt, economic growth, Pakistan.

\section{Introduction}

The relationship between debt and economic growth has always remain polemical. Large amount of debt has proved itself to be one of the greatest challenges faced by developing countries. Do high level of public debt impede economic growth? It is indeed an important policy question. A positive answer to it would suggest that even if public debt is effective in the short run, expansionary fiscal policies that increase the level of public debt would tend to reduce the long-run growth. Thus, the positive effects of the fiscal stimulus will be partly or fully negated. A number of policy makers argue that higher public debts turn down the economic growth. According to the IMF Fiscal affairs department "In addition to problems arising from a debt crisis, one should also be worried about problems for growth arising from high, even if stable, debt" (Cottarelli, 2011).

The debt acquired by any country is not a problem in itself, but the improper usage of debt could be a serious problem. When debt is allocated to low value adding activities and productivity level, because of being traditional activities, they are unable to generate wealth as per the required level of competitive advantage of the country. It also causes unemployment of qualified workforce of the country. Furthermore, a substantial amount of borrowed funds is directed towards payment of the public sector wages and remunerations. In this way, debt will not be helpful for the progress of the country.

The relationship between level of indebtedness and escalation of economic conditions has been studied by a number of researchers and their outcomes have been found contradictory in nature. According to the economic theory, a negative effect of debt on economic growth can be proved with both neo-classical and endogenous growth models

\footnotetext{
*PhD Scholar, Applied Economics Research Centre, University of Karachi. Email: amnarawat@gmail.com
} 
(Diamond, 1965; Saint-Paul, 1992). Public debt could more negatively affect the economic growth if it influences the productivity of public expenditures (Teles \& Mussolini, 2014), increases the level of uncertainty or creates expectations of future financial repression. It also creates sovereignty risk (Codogno, Favero, \& Missale, 2003). It will ultimately lead to higher real interest rates and lower private investment. Higher levels of accumulated debt has an adverse impact on the growth of the economy and investment. The most widely used explanation of this phenomenon is the 'Debt Overhang Effect'. If there is a possibility of increase in the amount of debt than the repayment ability of the country, then the anticipated cost of debt servicing will likely reduce the domestic and foreign investment (Krugman, 1988; Karagol, 2012). Another channel through which debt can affect economic growth is the crowding out effect. Debt servicing cost crowds out public investment expenditures by directly reducing total investments and indirectly reducing complementary private expenditures.

However, there are some studies that advocate the positive effect of debt on the economic growth. According to DeLong, Summers, Feldstein, and Ramey (2012), it is a possible scenario that expansionary fiscal policy lead to debt accumulation but may avoid lengthened recession ultimately leading to positive effect on both short and long term growth. A reasonable level of public debt can foster economic growth as it increases capital formation and growth in productivity (Chowdhury, 2001; Shabbir \& Zeb, 2019). In the same vein, (Burnside \& Dollar, 2000) argued that external borrowing for the sake of productive investments creates macroeconomic stability. A plausible reason of it could be, at early stages of development, countries have limited stocks and hence, limited opportunities of investment. With the inflow of capital with external debt, the investments increase creating macroeconomic stability. With this inflow of capital, the domestic saving rises to cater investment demand (Eaton, 1993).

Pakistan is one of a major growing economies of the South Asian region. According to the Pakistan Economic Survey, (2018), the GDP growth rate of the country was recorded to be 5.8 percent in the fiscal year 2018 as compared to 5.4 percent in the previous year. However, the growing indebtedness of the economy is the gravest concern for the policy makers. Pakistan Economic Survey, (2018) states that government is taking prudent steps to place the debt to GDP ratio on a smooth downward trajectory so as to boost up macroeconomic stability. However, the steps taken by the government seem in sufficient. In the fiscal year 2018, the net Public debt grew by 16.6 percent as compared to the previous fiscal year of 2017, (State Bank of Pakistan, 2018). The debt statistics of the economy shows a vulnerable situation. The policy makers and legislators need to focus on the growing indebtedness of the country and need to strive to reduce the debt to GDP ratios.

In this connection, the current study aims to explore the effects of external and domestic debt on the economic growth of Pakistan. More precisely, the study aims to answer the question, 'What are the effects of External and Domestic Debt on the Economic Growth of Pakistan?' To serve the purpose, the study utilizes annual time series data for the time period spanning from 1987-2018. Being an emerging economy of the world, it is of great importance to analyse that if the inflow of capital in form of debt is facilitating or inhibiting the growth of the economy. The study is expected to have its contribution in providing an econometric basis for evaluating the effect of debt on growth of economy. As per the 
findings of this study, practical policy conclusions could be drawn which may be useful for the policy makers, planners and researchers.

\section{Review of Related Literature}

Maana, Owino, and Mutai (2008) investigated the impact that domestic debt is having upon growth of Kenyan economy. The data was gathered for the tenure from 1996 to 2007, They have considered Modified Barro Growth Regression is estimation technique. Results showed that Domestic debt, and Government expenditure, private sector credit, and money supply (M3) and total trade are positively but insignificantly affect economic growth of Kenya. Akram (2016) studied the effect of public debt on growth of economy and investment of Pakistan, with the help of time series data from 1972 to 2009. The study used unit root test, CUSUM Test and regression for estimation purposes. Result showed that external debt has significant negative association with the growth of economy and investment in short term and in long term as well and debt servicing has significantly inverse relationship with the growth of economy in short run only but debt servicing does not have significant relationship with investment. Domestic debt has significant negative impact on investment but it has not significant relation with economic growth. The study further recommended that government should try to generate revenue and should not use debt to finance budget deficit.

Safdari and Mehrizi (2011) investigated the relationship of foreign debt with the growth of economy in Iran. Time series data has been utilized in this study covering the period from 1974 to 2007. Vector Auto Regression (VAR) technique was used for the purpose of estimation. The results expressed a negative effect of external debt on GDP while a positive relationship has been found out between private investment and pubic investment. Moreover, the variable of public investment had a positive impact whereas the variables of imports and external debt had an adverse impact on private investment. Shah and Pervin (2012) analyzed the effect of external debt with the growth of Bangladeshi economy considering time series for the tenure of 1974 to 2010. ADF Unit root test, Phillips-Perron Unit root test, Augmented Dickey - Fuller Cointegration test, and regression are used as Econometric tools. Result indicated that foreign debt has significantly favorable effect on the growth of economy whereas external debt servicing has significantly inverse relation with economic growth. Capital has an insignificantly negative impact on growth of economy and population has insignificantly positive impact on growth of economy. They recommended that external debt management should be efficient moreover government should not rely only on external debt to finance budget deficit. They further recommended that the excess saving should invest to finance budget deficit as there are huge gaps between saving and investment.

Atique and Malik (2012) studied the determinants of growth of Pakistani economy along with the effect of internal debt and foreign debt separately for the tenure of 30 years from 1980 to 2010. Ordinary Least Square (OLS) approach to Co integration was employed for the purpose of analysis. Further tests such as Unit Root Testing, test for checking Heteroskedasticity, Serial Correlation Testing, and CUSUM test of stability were 
also used. The results showed a significant negative relationship of domestic and foreign debt with the growth of economy. It was further been concluded that the amount of foreign debt hampers the pace of growth of economy for more than the amount of domestic debt could do. Egbetunde (2012) studied the relationship of total government debt on performance of Nigerian economy by using time series data for the year 1970 to 2010. Regression analysis, Co-integration test, unit root test, and Causality analysis were used for the purpose of estimation and analysis. Analysis showed a significant positive association of the total government debt with the growth of economy. The Co-integration confirms the existence of a long term association of public debt with real GDP. It also showed the presence of bidirectional granger causal effect between real growth level and public Debt. The Government was suggested to cover major part of loans domestically, so that at the time of repayment it could have positive impact on the growth. The government was also recommended to spend debt in the development sectors which could help in boosting up the growth of the economy.

Azam, Emirullah, Khan, and Prabharker (2013) studied the relationship of external debt with the growth of Indonesian economy by taking into account time series data from 1980 to 2012. Augmented Dickey Fuller (ADF) test and regression analysis were used as econometrics tools for estimation in the study. Result showed that external debt and inflation negatively affect the growth of economy whereas exports, savings and infrastructure have positive impact on economic growth. They suggested that effective debt management is very important to enhance the economic performance of Indonesia. Afonso and Jalles (2013) examined the effect of government debt on growth of 14 European countries using pool data from 1970 to 2012. Hausman test and regression analysis were used as estimation tools. Result indicated that Public debt negatively affect the growth of economy. Public debt servicing has also significant inverse association with growth of economy. Zouhaier and Fatma (2014) investigated the relationship of debt with the growth of economies of nineteen developing countries considering panel data for the period of 1990 to 2011. External debt, inflation, investment, Trade openness, Total debt, public and private debt guarantee, GDP per Capita and short term debt considered as variables. Panel GMM was used as econometric tool for estimation. Result denoted that external debt has significantly negative effect on growth of developing countries. The debt ratio to GNI has significant and inverse impact on economic growth. Trade Openness has significantly positive effect on economic performance.

Akram (2016) analyzed the relationship of public debt with investment and growth of Philippines' economy by using time series data from 1975 to 2010. Regression, bound F-test results, unit root test and CUSUM test was used for statistical estimations. Result indicated that external debt has significantly negative association with investment and growth of economy of Philippine, public debt has insignificant impact on investment and real GDP. Domestic debt has significant adverse effect on Investment but it has positive significant relation with economic growth. Bal and Rath (2014) investigated the relationship of public debt with growth of Indian economy for a period from 1980 to 2011. Auto-regressive distributed lag ARDL model was used for the purpose of analysis. A long-run equilibrium was found between public debt and economic. Error correction model (ECM) reflected that factor such as central government debt, total factor productiv- 
ity (TFP) growth, and debt-services have their effects, in the short-run, on the economic growth.

Korkmaz (2015) examined the linkage of foreign debt with Growth of Turkish Economy by considering Quarterly data from 2003 to 2014. PP Unit Root Test, Vector Auto regression (VAR) model, Johansen Co integration Test and Granger Causality Test have been used as estimation tools. Result explained that foreign debt has favorable association with the growth of Turkish economy and Granger Causality test reflected the presence of a unidirectional relationship in external debt and Real growth of Turkish Economy. Zafar, Sabri, Ilyas, and Kousar (2015) studied the association of foreign debt and Trade Openness with growth of economy of Middle East, East Asia and South Asia. They have considered Panel data for the periods of 1980 to 2012. External debt, Trade Openness, Foreign Direct Investment (FDI), Gross Domestic Product, Government Expenditure and savings have been used as variables. Descriptive Statistic, Unit Root test, Hausman Test and regression Analysis are used as estimation techniques. Result showed that trade openness has considerable favorable effect on growth of economy. External debt has significant inverse effect on Gross Domestic Product. They recommended that there should be taken effective steps towards debt management and trade barriers should be lessen for openness which ultimately enhance economic growth and debt management.

Serrão (2016) analyzed the association between Public debt and real economic growth of Advanced Economies using panel data ranging from 1946 to 2009. The Phillips-Perron test, Dickey-Fuller Test, Johansen's Co Integration Test, CUSUM Test and regression have been used as econometric estimation tools. Result indicated that public debt has inverse relationship with economic growth of Advance Economies. Researchers recommended that the Governments of the advance Economies should focus on debt management to enhance real economic growth. Fatai (2016) analyzed the association of external debt and debt servicing with growth of Nigerian economy considering time series data covering a period from 1970 to 2014. Augmented Dickey Fuller Test, The Philips-Perron (PP) test Johansen's Co Integration Test, regression test and Granger Causality Test have been used as estimation techniques. Result denoted that external debt has significantly negative association with growth of Nigerian economy whereas External Debt Servicing payment has positive impact on growth of economy. The Granger Causality analysis showed that there is bidirectional Causality from external debt to growth and debt servicing to growth of economy and unidirectional relationship from external debt to debt servicing.

Khemais, Mohamed, and Nesrine (2016) studied the effect of external debt with growth of economy and investment of Tunisia considering time series data for 1961 to 2011.External debt, Gross domestic Product, debt servicing, investment, trade openness, Money supply M2,schooling rate and Rules and law are used as Variables. Unit root test, Unrestricted Co integration rank test, regression analysis, Causality analysis and Pulse analysis were used as estimation tools. Results showed that investment and Schooling rate have positive significance relation with economic growth. External debt and debt servicing have significant negative relation with economic growth moreover Trade openness and M2 have negative relationship with growth. Jibran, Ali, Hayat, and Iqbal (2016) examined effect of public debt on growth of economy of Pakistan by analyzing a period from 1972 to 2012. Unit root test and Auto regressive distributed lag (ARDL) have been used 
as econometric tools for estimation. Result showed that External debt has significant inverse relationship with Gross Domestic Product and Gross National Products in shot run and in long run too. Debt servicing has negative impact on GNP and GDP. Domestic debt has no significant effect on GDP and GNP. They recommended that Pakistan should minimize the external debt due to its negative effect on economic growth. Moreover, Pakistan should focus on only debt financing to finance their budget deficit rather generate revenue from Tax reforms and also reduce current expenditures.

Akram (2016) analyzed the association between Public Debt and growth of economy and Poverty of selected South Asian nations i.e. Pakistan, Sri Lanka, Bangladesh and India by considering panel data for a tenure ranging from 1975 to 2010. Fixed Effect Model (FEM), OLS, Generalized Method of Moments (GMM) and Two Stages Least Square (2SLS) used as estimation techniques. Result showed that external debt adversely affect the growth of economy on the other side domestic debt, urbanization; trade openness and investment have positive significant impact on economic growth. Debt servicing and inflation have insignificant relationship with growth moreover in the second model in which GINI Coefficient was used as dependent variable, result indicated that Domestic debt and GDP per Capita have significant negative impact on GINI Coefficient whereas Trade Openness and Urbanizations have positive impact on GINI Coefficient. External debt and debt servicing have insignificant relation with GINI Coefficient.

\section{Data}

In this study, an annual data of, Pakistan is used. The selected sample consist of 32 years of data for a time period spanning from 1987 to 2018. Data were collected from World Development Indicators, State Bank of Pakistan and Economic Survey of Pakistan.

\section{Econometric Specification}

To explore the relationship between public debt and economic growth, we build an influential framework based on the study of Cecchetti, Mohanty, and Zampolli (2011); Panizza and Presbitero (2014); Akram (2016). We stay as close as possible to their work by using the same empirical approach. The econometric specification used for the study can be stated as follows,

$$
G D P=f(E D, D D, X)
$$

Where, GDP; is the Gross Domestic Product, ED; is the external debt, DD; is domestic debt and $\mathrm{X}$ is the vector of control variables, which includes debt servicing, capital formation, trade openness, inflation and gini index.

The regression equation for the given functional form can be written as,

$$
G D P=\beta_{0}+\beta_{1} E D_{t}+\beta_{2} D D_{t}+\beta_{3} D S_{t}+\beta_{4} G i n i_{t}+\beta_{5} O P_{t}+\beta_{7} I n f_{t}+\beta_{8} K_{t}+\epsilon_{t}
$$


A brief description of all variables used in the study is given below,

Gross Domestic Product (GDP): Gross domestic product is the measure of the total output produced by an economy in a given year. The size of GDP represents the growth of the economy.

Inflation (INF): Inflation is increasing in the general price level of goods and services available in specific country and in the specific time duration. Inflation is measured in percentage of annual change in prices.

Capital Formation (K): It refers to the net increase in the physical assets of the economy. It is used to measure economy's capital formation.

External Debt (ED): External debts are those which are borrowed from the foreign financial institutions.

Domestic Debt (DD): Domestic debt is the portion of the entire debt of the government which is borrowed from within the country's financial institutions or investors.

Trade Openness (OP): The Openness is an economic metric as the proportion of total trade of the country, the sum of all economic activity i.e. exports and imports, to the GDP of country.

Debt Servicing (DS): Debt service is activity of generating cash that is used to require refunding the interest on a loan for a specific period.

Gini Index (GINI): According to the World Bank, Gini index measures the extent to which the distribution of income (or, in some cases, consumption expenditure) among individuals or households within an economy deviates from a perfectly equal distribution. Thus a Gini index of 0 represents perfect equality, while an index of 100 implies perfect inequality.

\section{Data Analysis}

\section{Unit Root Test}

The analysis is started with unit root test to examine the stationary properties of the variables. This test must be performed in order to avoid spurious regression results (Sehrawat \& Giri, 2017). We have used Augmented Dickey Fuller (ADF) test to testify the stationary properties of our variables. The null hypothesis of unit root test states that there is a unit root in each series, whereas, the alternate hypothesis states that, no unit root exist in each series.

Table 1 presents results of the unit root test. As can be seen from the table, all variables are non stationary at level but stationary at 1st difference. This implies that combinations of one or more series may have long run relationship. 
Table 1

\begin{tabular}{lcccc} 
Unit Root Test & \multicolumn{3}{c}{ I(1) } \\
\hline Variables & \multicolumn{2}{c}{$\mathbf{I}(\mathbf{0})$} & \multicolumn{3}{c}{ C } & C\&T \\
\hline Log(GDP) & 0.988 & 0.2 & $0.0025^{* * *}$ & $0.017^{* * *}$ \\
GINI & 0.24 & 0.913 & $0.000^{* * *}$ & $0.000^{* * *}$ \\
DD & 0.9195 & 0.253 & $0.0192^{* * *}$ & $0.0638^{* * *}$ \\
DS & 0.321 & 0.423 & $0.0000^{*}$ & $0.000^{* * *}$ \\
ED & 0.577 & 0.306 & $0.0041^{* * *}$ & $0.0170^{* * *}$ \\
INF & 0.877 & 0.566 & $0.000^{* * *}$ & $0.000^{* * *}$ \\
K & 0.817 & 0.624 & $0.0025^{* *}$ & $0.0196^{*}$ \\
OP & 0.448 & 0.932 & 0 & 0.0001 \\
\hline Source: Author's Estimation & \\
* represents 10\%, ** represents 5\%, and *** represents \\
1\% level of significance
\end{tabular}

\section{Cointegration Test}

To estimate the long run relationship, we used Johansen and Juselius (1990) cointegration method. Two test statistics are derived for cointegration i.e., Eigen value statistics and Trace statistics. The calculated Eigen value statistics and Trace statistics are presented in table 2 given below. From the results, it can be seen that the calculated trace and eigen value statistics are greater than $5 \%$ critical values. Hence, the null hypothesis of no cointegration is rejected and a long run relationship exists among all variables under study.

Table 2

\begin{tabular}{|c|c|c|c|c|}
\hline \multicolumn{5}{|c|}{ Cointegration Test } \\
\hline $\begin{array}{l}\text { Hypothesized } \\
\text { No. of CE(s) }\end{array}$ & $\begin{array}{c}\text { Trace } \\
\text { Statistic }\end{array}$ & $\begin{array}{c}0.05 \\
\text { Critical Value }\end{array}$ & $\begin{array}{c}\text { Max-Eigen } \\
\text { Statistic }\end{array}$ & $\begin{array}{c}0.05 \\
\text { Critical Value }\end{array}$ \\
\hline None* & 321.938 & 159.529 & 119.251 & 52.362 \\
\hline At most $1^{*}$ & 202.686 & 125.615 & 72.807 & 46.231 \\
\hline At most $2 *$ & 129.878 & 95.753 & 51.626 & 40.077 \\
\hline At most $3 *$ & 78.251 & 69.818 & 34.616 & 33.876 \\
\hline
\end{tabular}

\section{Regression Estimates}

The study has also employed fully modified ordinary least squares (FMOLS), dynamic ordinary least squares (DOLS) and ordinary least squares (OLS) to estimate the relationship between economic growth and debt. The FMOLS technique was presented by Phillips and Hansen (1990) and DOLS was proposed by Kao (1999). These two techniques are beneficial in determining co-integrated relationships and provide normally distributed estimators. The OLS technique is modified by FMOLS to control the problem of endogeneity and serial correlation due to presence of co-integrated relationship among the variables. It is argued that both FMOLS and OLS show small sample bias however, DOLS method outpaces both of these two techniques. DOLS technique also substantially deals with the problem of serial correlation and potential endogeneity problem in the model (Stock \& Watson, 1993). Estimation results are presented in table 3 given below. It suggests that, external and domestic debt have negative impact on economic growth for Pakistan. Whereas, debt servicing is found to have positive impact on economic growth. Gini 
index is also found to have positive impact on the growth of Pakistan's economy. Moreover, capital formation, inflation, and trade openness have been found to have positive linkages with the economic growth in all models.

Table 3

Estimation Results

\begin{tabular}{ccccccc}
\hline & \multicolumn{2}{c}{ FMOLS } & \multicolumn{2}{c}{$\begin{array}{c}\text { Pakistan } \\
\text { DOLS }\end{array}$} & \multicolumn{2}{c}{ OLS } \\
\hline Variable & Coefficient & Prob. & Coefficient & Prob. & Coefficient & Prob. \\
\hline ED & -0.024 & $0.005^{* * *}$ & -0.107 & $0.012^{* *}$ & -0.035 & 0.136 \\
DD & -0.007 & 0.562 & -0.114 & $0.002^{* * *}$ & -0.018 & 0.39 \\
DS & 0.014 & $0.093^{*}$ & 0.055 & 0.127 & 0.114 & $0.000^{* * *}$ \\
GINI & 0.008 & 0.611 & 0.083 & $0.096^{*}$ & 0.006 & 0.15 \\
K & 0.055 & $0.000^{* * *}$ & 0.168 & $0.092^{*}$ & 0.266 & $0.000^{* * *}$ \\
INF & 0.121 & $0.001^{* * *}$ & 0.338 & $0.005^{* * *}$ & 0.004 & 0.455 \\
OP & 0.043 & $0.095^{*}$ & 5.093 & 0.17 & 0.115 & $0.060^{*}$ \\
C & -1.403 & 0.424 & -0.107 & 0.012 & -0.382 & 0.692 \\
Adjusted R-squared & \multicolumn{2}{c}{0.979} & \multicolumn{2}{c}{0.999} & & 0.981 \\
\hline
\end{tabular}

Source: Author's Estimation

${ }^{*}$ represents $10 \%,{ }^{* *}$ represents $5 \%$ and ${ }^{* * *}$ represents $1 \%$ level of significance

\section{Figure 1}

CUSUM and CUSUMSQ results
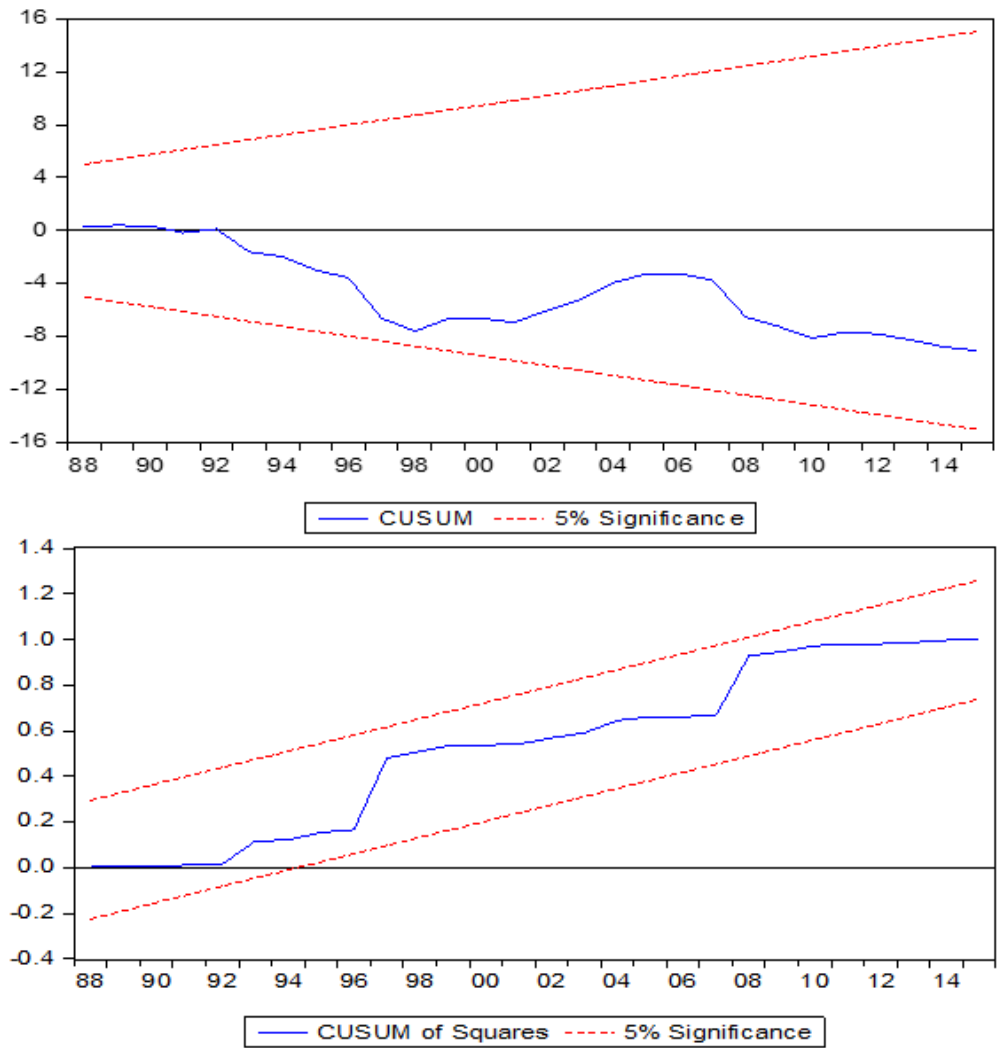
To check parameter stability, CUSUM and CUSUMSQ of recursive residuals test have also been used (Ploberger \& Krämer, 1992). Figure 1 presents the results. The results indicate no evidence of instability of coefficients as the plot of CUSUM and CUSUMSQ statistics fall inside the band of 5\% significance level.

\section{Discussion}

The study found that external debt has a negative impact on the growth of the economy. This result finds it support from various past empirical studies, for instance, (Abbas \& Christensen, 2010; Azam et al., 2013) and many more. The reason of this negative relationship could be that when the domestic resources of the country are utilized and exploited for the repayment of debt, resources do not remain available for the investment purposes. Hence, the study confirms the existence of Debt overhang effect which states that if the debt burden of the country exceeds its repayment ability, it dissuades current investments as most of the financial resources are used in the repayment of debt.

The study also found the empirical evidence of negative effect of domestic debt on the economic growth. Various past researches also lend support to this finding for example, Atique and Malik (2012) etc. Domestic debt can have negative impact on the economic growth as it causes 'crowding out' effect of private investment. When government borrowings from the domestic financial institutions increases, it increases the interest rate in the economy which consequently crowds out private investment, slowing down the pace of economic growth.

However, interestingly, debt servicing has been found to have positive association with the economic growth. This finding does not conform to the past studies on the subject. The economic theory suggests that as the debt servicing increases, it engulfs the financial resources and they do not remain available for the investment purposes. On the contrary, our analysis suggests a positive relationship between debt servicing and economic growth. The reason could be explained using Keynesian economic theory. Developing countries like Pakistan increase their money supply for debt servicing. With this increase of money supply, the economy may also experience growth in short run. However, in the longer run, this effect wipes off because of increase in the price level in economy.

Contrary to our expectations, gini index was found to have positive relationship with the growth of the country. The results are quite surprising for the panel. However, the time series analysis of the countries revealed that for Pakistan, this relationship is positive and significant according to the DOLS model while FMOLS reports it to be insignificant. However, for India, this relationship is insignificant and negative. According to Ogus Binatli (2012), the relationship between income inequality and growth is still ambiguous. Mostly because of the unreliable data and the complex relationship between income inequality and growth, consensus has been evasive.

In accordance with economic theory, investment is found to have positive impact on economic growth and this finding gets its support from various past studies on the subject, (Mankiw, Romer, \& Weil, 1992; Abbas \& Christensen, 2010). Similarly, openness is 
also found to have growth enhancing effect. This finding is also consistent with the economic theory and various empirical studies lend support to this finding. As the openness in the economy increases, it depicts more competitiveness and productivity of the economy which ultimately causes growth in the economy. Moreover, inflation is also found to have positive impact on the growth. According to the economic theory, moderate level of inflation facilitates the growth of economy. However, if the inflation rates increase, it may create economic distortion and suppress economic growth (Akram, 2016).

\section{Conclusion and Policy Implications}

The aim of the present study was to examine the impact of external and domestic debt on the growth of the economy. For this purpose, the study employed panel data for the time period spanning from 1987 to 2018 for Pakistan. To meet the objective, the study has employed fully modified ordinary least squares technique, dynamic ordinary least squares technique and ordinary least squares technique. All econometric tools applied gave robust results in terms of signs, however, the magnitude of the coefficients differ slightly in all models.

The study has employed a framework that has considerable appeal in terms of modelling growth-debt relationship. The principal finding of the study is that external and domestic debt have detrimental effects on growth. This finding is very important and fiscal legislators need to give considerable attention to it. Heavy indebtedness is one of the main challenges faced by the developing nations. Government borrowings, if pushed beyond the repayment capacity of the economy, creates problems of inter-temporal equity and also causes a transfer of resources that tends to reduce growth of economy. Yet, borrowing has to be done to finance the vital government expenditures in developing countries. A worthwhile notion to make is that a reasonable level of borrowings may enhance economic growth by capital formation and increase in productivity, however, when the debt burden increases, it reduces the level of investment and rate of economic growth which is most often characterized as 'Debt Overhang Effect'. Because of the increased debt burden, developing countries are caught up in a 'vicious circle of debt' that causes recession, budget deficits and inflating public deficit. According to Panizza and Presbitero (2014), there is a channel through which public debt can have negative impact on the economic growth. In the presence of multiple equilibria, a solvent government with a high level of debt may decide to put in place restrictive fiscal policies to reduce the probability that a sudden change in investors' sentiments would push the country towards the bad equilibrium. These policies reduce the growth of economy.

Keeping in view the findings of the study, several policy implications can be given. The foremost implication of the study is since there is a negative relationship between external debt and economic growth, so governments of both of these countries should reduce reliance on external debt. Moreover, domestic debt was also found to have deteriorating effects on the economic growth, therefore, there is a dire need of enhancing tax and non-tax revenues to finance the fiscal expenditures.

The study did not support the hypothesis that debt servicing have significant negative 
impact on growth. The point is that, although, debt servicing may hinder the economic growth. However, it should be seen in relation to the factors like effective endowment of debt. If public debt is utilized for financing development expenditures, it may facilitate growth. However, developing countries usually increase their money supply to finance the debt servicing. This increases the growth in the short run. But, in the long run, when the potential macroeconomic equilibrium is restored, the growth effect vanishes and the price level in the economy increases. Therefore, government of developing countries should work on the effective utilization of debt so that the debt burden may reduce.

The findings of the present study also emphasized the importance of trade openness as a growth stimulating factor. So if a country wants to accelerate the pace of economic growth, it should work towards increasing its trade volume. As both countries included in the panel are labour intensive, therefore, preference should be given to those sectors of the economy that are labour intensive so that unemployment can also be reduced. In this way, economic growth may foster.

\section{Future Recommendations}

The future areas for further research are always interesting to be highlighted. The study has though reported a crowding out effect of public debt for developing countries like India and Pakistan. However, for examination of the hypothesis, it is suggested to extend the panel across the world and different income levels so that more precise empirical evidence can be collected. Moreover, the inclusion of development expenditures and military expenditures in the growth model would also help in further exploration of the hypotheses. 


\section{References}

Abbas, S. A., \& Christensen, J. E. (2010). The role of domestic debt markets in economic growth: An empirical investigation for low-income countries and emerging markets. IMF Staff Papers, 57(1), 209-255.

Afonso, A., \& Jalles, J. T. (2013). Growth and productivity: The role of government debt. International Review of Economics \& Finance, 25, 384-407.

Akram, N. (2016). Public debt and pro-poor economic growth evidence from South Asian countries. Economic Research-Ekonomska Istraživanja, 29(1), 746-757.

Atique, R., \& Malik, K. (2012). Impact of domestic and external debt on the economic growth of Pakistan. World Applied Sciences Journal, 20(1), 120-129.

Azam, M., Emirullah, C., Khan, A., \& Prabharker, A. (2013). The role of external debt in economic growth of Indonesia-A blessing or burden? World Applied Science Journal, 25(8), 1150-1157.

Bal, D. P., \& Rath, B. N. (2014). Public debt and economic growth in india: A reassessment. Economic Analysis and Policy, 44(3), 292-300.

Burnside, C., \& Dollar, D. (2000). Aid, policies, and growth. American Economic Review, 90(4), 847-868.

Cecchetti, S. G., Mohanty, M., \& Zampolli, F. (2011). Achieving growth amid fiscal imbalances: The real effects of debt. In Economic symposium conference proceedings (Vol. 352, pp. 145-96).

Chowdhury, A. (2001). External debt and growth in developing countries: a sensitivity and causal analysis. WIDER-Discussion Papers.

Codogno, L., Favero, C., \& Missale, A. (2003). Yield spreads on emu government bonds. Economic Policy, 18(37), 503-532.

Cottarelli, C. (2011). The risk octagon: A comprehensive framework for assessing sovereign risks. University of Rome "La Sapienza,".

DeLong, J. B., Summers, L. H., Feldstein, M., \& Ramey, V. A. (2012). Fiscal policy in a depressed economy [with comments and discussion]. Brookings Papers on Economic Activity, 233-297.

Diamond, P. A. (1965). National debt in a neoclassical growth model. The American Economic Review, 55(5), 1126-1150.

Eaton, J. (1993). Sovereign debt: A primer. The World Bank Economic Review, 7(2), 137-172.

Egbetunde, T. (2012). Public debt and economic growth in Nigeria: Evidence from granger causality. American Journal of Economics, 2(6), 101-106.

Fatai, O. (2016). Causal nexus between external debt and economic growth: The Nigerian case. International Journal of Management and Commerce Innovations, 4(1), 92-98.

Jibran, K., Ali, A., Hayat, U., \& Iqbal, A. (2016). Public debt and economic growth in Pakistan: A reassessment. Pakistan Business Review, 18(2), 307-324.

Kao, C. (1999). Spurious regression and residual-based tests for cointegration in panel data. Journal of Econometrics, 90(1), 1-44.

Karagol, E. (2012). The causality analysis of external debt service and GNP: The case of Turkey. Central Bank Review, 2(1), 39-64. 
Khemais, Z., Mohamed, M., \& Nesrine, D. (2016). External debt \& economic growth: Case of Tunisia. International Journal of Economics and Finance, 8(6), 129-140.

Korkmaz, S. (2015). The relationship between external debt and economic growth in Turkey. In Proceedings of the Second European Academic Research Conference on Global Business, Economics, Finance and Banking (EAR15Swiss Conference) ISBN.

Krugman, P. R. (1988). Financing vs. forgiving a debt overhang. Journal of Development Economics, 29, 253-268.

Maana, I., Owino, R., \& Mutai, N. (2008). Domestic debt and its impact on the economythe case of Kenya. In 13th Annual African Econometric Society Conference in Pretoria, South Africa (Vol. 40).

Mankiw, N. G., Romer, D., \& Weil, D. N. (1992). A contribution to the empirics of economic growth. The Quarterly Journal of Economics, 107(2), 407-437.

Ogus Binatli, A. (2012). Growth and income inequality: A comparative analysis. Economics Research International, 2012.

Panizza, U., \& Presbitero, A. F. (2014). Public debt and economic growth: Is there a causal effect? Journal of Macroeconomics, 41, 21-41.

Phillips, P. C., \& Hansen, B. E. (1990). Statistical inference in instrumental variables regression with i (1) processes. The Review of Economic Studies, 57(1), 99-125.

Ploberger, W., \& Krämer, W. (1992). The cusum test with OLS residuals. Econometrica: Journal of the Econometric Society, 271-285.

Safdari, M., \& Mehrizi, M. A. (2011). External debt and economic growth in Iran. Journal of Economics and International Finance, 3(5), 322-327.

Saint-Paul, G. (1992). Fiscal policy in an endogenous growth model. The Quarterly Journal of Economics, 107(4), 1243-1259.

Sehrawat, M., \& Giri, A. (2017). An empirical relationship between financial development indicators and human capital in some selected asian countries. International Journal of Social Economics, 44(3), 1194-1208.

Serrão, A. (2016). Impact of public debt on economic growth in advanced economies. International Journal of Managerial Studies and Research, 4(2), 70-76.

Shabbir, M. S., \& Zeb, A. (2019). Determinants of economic stability through female unemployment: Evidence from Pakistan. Journal of Finance and Economics Research, 4(1), 19-30.

Shah, M., \& Pervin, S. (2012). External public debt and economic growth: Empirical evidence from Bangladesh, 1974 to 2010. Academic Research International, 3(2).

Stock, J. H., \& Watson, M. W. (1993). A simple estimator of cointegrating vectors in higher order integrated systems. Econometrica: Journal of the Econometric Society, 783-820.

Teles, V. K., \& Mussolini, C. C. (2014). Public debt and the limits of fiscal policy to increase economic growth. European Economic Review, 66, 1-15.

Zafar, M., Sabri, P. S. U., Ilyas, M., \& Kousar, S. (2015). The impact of trade openness and external debt on economic growth: New evidence from South Asia, East Asia and Middle East. Science International, 27(1).

Zouhaier, H., \& Fatma, M. (2014). Debt and economic growth. International Journal of Economics and Financial Issues, 4(2), 440-448. 